\title{
PENERAPAN METODE EKSPERIMEN UNTUK MENINGKATKAN KETUNTASAN BELAJAR PADA PEMBELAJARAN SAINS DI KELAS V SDN 101896 KIRI HULU 1
}

\author{
Effendi Manalu \\ Dosen Jurusan PPSD Prodi PGSD FIP UNIMED \\ Surel : e.manalu@gmail.com
}

\begin{abstract}
ABSTRAK
Tujuan dari penelitian ini yaitu untuk mengumpulkan data dan membuktikan penerapan Metode Eksperimen untuk meningkatkan ketuntasan belajar pada pembelajaran Sains di Kelas V SDN 101896 Kiri Hulu 1. Jenis Penelitian ini adalah penelitian tindakan kelas (PTK). Penelitian ini terdiri dari dua siklus. Subjek dalam penelitian ini adalah siswa kelas $\mathrm{V}^{\mathrm{A}}$ SDN 101896 Kiri Hulu 1 Tanjung Morawa dengan jumlah siswa 39 orang. Alat pengumpul data yang digunakan dalam penelitian ini adalah tes, observasi, dan dokumentasi.

Dari hasil penelitian pada siklus I rata-rata hasil observasi pengamatan terhadap guru sebesar 60 dan meningkat pada siklus II menjadi 86,25. Sedangkan hasil pengamatan terhadap siswa pada siklus I memiliki rata-rata 57,5 dan meningkat pada siklus II sebesar 85 . Berdasarkan hasil penelitian diperoleh pada kondisi awal atau sebelum diberi tindakan terdapat 34 siswa ( $87 \%$ ) yang belum tuntas belajar dan 5 orang ( $13 \%$ ) yang tuntas belajar dengan nilai rata-rata 55,51. Pada siklus I terdapat 20 siswa ( $51 \%$ ) yang belum tuntas belajar dan 19 siswa ( $49 \%$ ) yang tuntas belajar dengan nilai rata-rata 69,35 . Pada siklus II terjadi peningkatan yaitu : terdapat 36 siswa ( $92 \%$ ) yang tuntas belajar dan 3 orang siswa ( $8 \%$ ) yang belum tuntas belajar dengan nilai rata-rata 80,25 .
\end{abstract}

Kata Kunci : Eksperimen, Ketuntasan Belajar, Sains

\section{PENDAHULUAN}

Pendidikan Sains adalah salah satu pembelajaran yang dianggap penting karena ilmunya dapat diterapkan secara langsung dimasyarakat. Namun pembelajaran sains di SD saat ini banyak dikeluhkan sulit, dan harus diubah sedemikian rupa sehingga jadi menyenangkan. Masih banyak siswa SD yang kurang mengerti dan memahami pembelajaran Sains. Padahal Sains sendiri adalah salah satu mata pelajaran yang dianggap mampu meningkatkan daya nalar, kemampuan dan kreativitas siswa dalam berpikir. Pembelajaran Sains berguna bagi kehidupan atau pekerjaan anak dikemudian hari, bagian kebudayaan bangsa, melatih anak berpikir kritis, dan mempunyai nilai-nilai pendidikan yaitu mempunyai potensi dapat membentuk pribadi anak secara keseluruhan. Selain itu, Pembelajaran Sains juga diharapkan tidak hanya memberikan kemampuan supaya siswa dapat memecahkan soal-soal yang berkaitan dengan konsep Sains, tetapi secara konkrit dapat membentuk cara berpikir kritis, logis dan dapat memecahkan masalah dengan kreatif dan inovatif.

Sains sebagai bagian dari pendidikan umumnya juga memiliki peran penting dalam peningkatan mutu pendidikan. Dalam mengembangkan pembelajaran Sains sangat diharapkan keterlibatan aktif seluruh siswa dalam kegiatan pembelajaran. Menemukan sendiri pengetahuan melalui interaksi dengan lingkungannya. Intinya 
pembelajaran yang dikehendaki menurut kurikulum tingkat satuan pendidikan adalah pembelajaran yang tidak mengabaikan hakikat Sains dan mencerminkan sifat Sains sebagai ilmu pengetahuan alam. Sains seharusnya dibelajarkan secara ilmiah untuk menumbuhkan kemampuan berpikir, bekerja dan bersikap ilmiah, serta berkomunikasi sebagai salah satu aspek penting dalam kehidupan sehari-hari. Pembelajaran Sains di SD menekankan pada pemberian pengalaman belajar secara langsung melalui penggunaan dan pengembangan metode belajar dan sikap ilmiah.

materi $\begin{array}{ccc}\text { Khususnya dalam memahami } \\ \text { sifat-sifat cahaya dan }\end{array}$
penerapannya yang sangat berguna dalam kehidupan sehari-hari. Sebab materi sifatsifat cahaya cukup sulit untuk di pahami oleh siswa jika metode pembelajarannya lebih berpusat pada guru. Karena untuk memahami materi tersebut di perlukan suatu percobaan yang melibatkan siswa secara langsung untuk membuktikan kebenaran konsep pembelajaran. Dengan cara ini siswa akan lebih mudah memahami materi yang di ajarkan. Fenoma dilapangan menunjukan bahwa pembelajaran Sains di sekolah, khusunya materi sifat-sifat cahaya dan penerapannya sebagian besar guru masih mendominasi proses belajar dengan menerapkan pendekatan pembelajaran konvensional dan metode utama. Maksudnya dalam proses belajar mengajar masih menggunakan cara yang lama, yaitu penyampaian pelajaran pengajar masih mengandalkan ceramah. Ceramah itulah yang masih dijadikan metode utama dalam pelaksanaan pembelajaran Sains di dalam kelas, sehingga membuat siswa kurang aktif dalam kegiatan pembelajaran dan cepat merasa jenuh. Siswa cenderung hanya mendengarkan dan mencatat penjelasan dari guru. Dengan hanya menerapkan metode ceramah siswa lebih sering membayangkan tanpa tahu membuktikan kebenaran dari teori dan materi yang dijelaskan.

Dari hasil pengamatan dan observasi awal pada tanggal 24 Desember 2014 di SDN 101896 Kiri Hulu 1, menjelaskan bahwa ada beberapa permasalahan yang dihadapi guru dalam melaksanakan pembelajaran tak terkecuali pada pembelajaran Sains. Berbagai permasalahan tersebut diantaranya masih ditemukan beberapa guru yang tidak menggunakan media pembelajaran, padahal kehadiran media dalam kelas merupakan hal yang sangat penting bagi siswa SD untuk mengembangkan kemampuan berpikirnya dan ketuntasan belajaranya. Selain itu, bentuk metode pembelajaran dan teknik yang digunakan guru hanya sebatas penggunaan ceramah, hafalan, mencatat.

Maka diketahui bahwa dari 40 siswa pada semester I tahun ajaran 2013/2014 terdapat sebanyak 15 orang siswa $(37,5 \%)$ yang mendapat nilai tuntas dan 25 orang $(62,5 \%)$ siswa tidak tuntas. Pada semester II tahun ajaran 2013/20114 sebanyak 17 orang siswa $(42,5 \%)$ yang mendapat nilai tuntas dan 23 orang $(57,5 \%)$ siswa tidak tuntas. selanjutnya pada semester I tahun ajaran 2014/2015 sebanyak 13 orang siswa $(32,5 \%)$ yang mendapat nilai tuntas dan 27 orang $(67,5 \%)$ siswa tidak tuntas. Pembelajaran Sains dikatakan tuntas apabila persentase ketuntasan lebih dari $75 \%$ jumlah siswa lulus kriteria ketuntasan minimal (KKM). Sedangkan dari tabel yang diamati persentase siswa menunjukkan bahwa dalam tiga semester ketuntasan belajar siswa dibawah $75 \%$. Dengan demikian maka secara klasikal hasil belajar siswa pada mata pelajaran Sains belum tuntas.

Untuk mengantisipasi hasil belajar siswa agar dapat ditingkatkan maka tugas guru tidak hanya sekedar mengupayakan siswa untuk memperoleh berbagai 
pengetahuan produk dan keterampilan. Bahkan harus lebih dari itu, guru harus dapat mendorong siswa untuk mampu belajar secara mandiri dalam rangka menumbuhkan daya nalar, cara berpikir logis, sistematis, kreatif, cerdas, terbuka, dan ingin tahu. Oleh sebab itu dalam kegiatan belajar mengajar perlu dikembangkan pengalaman belajar melalui strategi pembelajaran yang sesuai. Upaya ini dapat dilakukan guru melalui penerapan metode eksperimen dalam pembelajaran.

Pembelajaran dengan metode eksperimen menempatkan siswa kedalam situasi yang melibatkan mereka dalam kegiatan-kegiatan intelektual. Maksudnya kegiatan yang berhubungan dengan berbagai aktivitas mental berpikir, menalar, dan memecahkan masalah. Metode eksperimen memberikan kesempatan kepada siswa untuk belajar mengembangkan potensi intelektualnya sendiri melalui suatu percobaan, sehingga siswa terdorong untuk ikut bertindak aktif mencari jawaban atas masalah-masalah yang dihadapinya dan dapat menarik kesimpulan melalui proses berpikir ilmiah yang kritis, logis, dan sistematis. Sehingga membuat siswa percaya pada kebenaran kesimpulan percobaannya sendiri dari pada menurut cerita orang atau buku. Siswa aktif mengumpulkan fakta, informasi atau data yang diperlukan melalui percobaan yang dilakukan. Hasil belajar dikuasai siswa dengan baik dan tahan lama dalam ingatan.

Berdasarkan uraian di atas, peneliti merasa masalah ini sangat penting untuk diteliti karena jika tidak ketuntasan belajar Sains akan sulit tercapai. Maka penulis tertarik untuk melakukan penelitian dengan judul "PENERAPAN METODE

EKSPERIMEN

UNTUK

MENINGKATKAN KETUNTASAN

BELAJAR PADA PEMBELAJARAN

SAINS DI KELAS V SDN 101896 KIRI HULU 1"

\section{METODE PENELITIAN Jenis Penelitian}

Jenis penelitian ini adalah Penelitian Tindakan Kelas (Classroom Action Research) dengan menggunakan metode eksperimen sebagai sasaran utama. Dimana penelitian ini berupaya memaparkan penerapan metode eksperimen untuk meningkatkan ketuntasan belajar pada pembelajaran SAINS di kelas V SD Negeri 101896 Kiri Hulu 1 Tanjung Morawa.

Pendekatan yang dilakukan adalah pendekatan kuantitatif yaitu penelitian evaluasi yang dilakukan untuk mengetahui keterlaksanaan suatu kebijakan. Jika ada hambatan dapat diketahui kemudian dapat menentukan cara-cara dalam rangka mengatasi masalah yang di maksud. Dimana peneliti ini menggambarkan data dalam bentuk angka yang sifatnya kuantitatif.

Penelitian ini menggunakan tes sebagai instrument penelitian. Tes hasil belajar disusun dalam bentuk tes pilihan berganda yang berupa soal berdasarkan materi yang diajarkan kepada siswa dengan jumlah soal sebanyak 20.

Sedangkan untuk pelaksanaan penerapan metode eksperimen dilakukan dengan observasi yang dilakukan pada saat kegiatan belajar mengajar berlangsung.

Desain penelitian yang dilaksanakan adalah desain yang menggunakan mode Kemmis dan Taggart (dalam Dewi, Rosmala. 2010: 122)

Untuk mengetahui persentase hasil siswa pada materi sifat-sifat cahaya digunakan rumus :

$\mathbf{P P H}=\frac{\boldsymbol{B}}{\boldsymbol{N}} \mathbf{x} \mathbf{1 0 0 \%}($ Aqib, $2008: 14)$

Keterangan :

PPH : Persentase Penilaian Akhir

B : Skor yang diperoleh siswa

N : Skor Maksimal 
Kriteria :

$0 \% \leq \mathrm{PPH}>70 \%$ Siswa belum tuntas dalam belajar

$75 \% \leq \mathrm{PPH} \leq 100 \%$ Siswa sudah tuntas dalam belajar

Dengan kriteria-kriteria ketuntasan belajar

- $86-100=$ sangat baik = tuntas

- $76-85=$ baik = tuntas

- $75=$ sedang = tuntas

- $<75=$ rendah = belum tuntas

Selanjutnya dapat juga diketahui pakah ketuntasan secara klasikal telah tercapai, dilihat dari persentasi siswa yang sudah tuntas dalam belajar dapat dirumuskan sebagai berikut.

PKK $=\frac{\text { banyaknya siswa yang } K K M \geq 70 \%(m)}{\text { banyaknya siswa }(n)} \times 100$ ( Aqib, 2008:14)

Keterangan :

PKK : Persentase Ketuntasan Maksimal

m : Jumlah siswa yang tuntas

n : Jumlah siswa dalam satu kelas

Seorang siswa dikatakan tuntas jika $\mathrm{PPH} \geq 75 \%$, sedangkan suatu kelas dikatakan tuntas jika PKK > $100 \%$ Jadi, nilai siswa dikatakan tuntas apabila persentase menunjukan diatas $75 \%$, dan tidak tuntas jika dibawah $75 \%$.

Dan dalam penelitian juga mengadakan lembar observasi guna melihat keadaan siswa dan guru selama pembelajaran berlangsung. Dari observasi ini di harapkan siswa yang mengalami kesulitan dapat diketahui oleh pengamat, di mana sebagai pengamat adalah guru kelas.

\section{HASIL PENELITIAN PEMBAHASAN \\ DAN}

Secara keseluruhan, keterlibatan siswa dalam proses pembelajaran SAINS materi sifat-sifat cahaya dan penerapannya di kelas V SD Negeri No. 101896 Kiri Hulu 1 Tanjung Morawa menunjukkan bahwa metode pembelajaran yang melibatkan siswa seperti metode eksperimen dapat meningkatkan hasil belajar siswa. Hal ini dapat dilihat dari peningkatan hasil belajar siswa dalam menyelesaikan soal - soal yang diberikan guru. Hal ini terbukti dari hasil pencapaian siklus II yang menunjukkan nilai rata-rata 80,25 dan secara klasikal 92, $30 \%$.

Sebelum peneliti menerapkan Metode Eksperimen hasil pretest menunjukkan bahwa 5 orang atau $13 \%$ yang mencapai nilai ketuntasan. Sedangkan pada siklus I, siswa yang mencapai ketuntasan belajar sebanyak 19 orang atau $49 \%$, hal ini menunjukkan belum tercapainya indikator keberhasilan yang telah ditetapkan oleh peneliti yaitu ketuntasan secara klasikal $>75 \%$. Oleh karena itu peneliti memperbaiki rancangan tindakan pada siklus II untuk dapat memenuhi indikator keberhasilan yang telah ditetapkan sebelumnya. Dari hasil post test yang dilakukan pada akhir siklus II menunjukkan bahwa terjadi peningkatan hasil belajar siswa menjadi 26 orang atau $90 \%$ siswa yang berhasil memenuhi indikator keberhasilan.

Tabel Peningkatan Nilai Rata-rata dan Ketuntasan Secara Klasikal

\begin{tabular}{|c|c|c|c|}
\hline No & $\begin{array}{c}\text { Jenis } \\
\text { Tes }\end{array}$ & $\begin{array}{c}\text { Nilai Rata- } \\
\text { rata }\end{array}$ & $\begin{array}{c}\text { Ketuntasa } \\
\text { Klasikal }\end{array}$ \\
\hline 1. & Pretest & 55,51 & $12,8 \%$ \\
\hline 2. & $\begin{array}{c}\text { Post Tes } \\
\text { Siklus I }\end{array}$ & 69,35 & $48,71 \%$ \\
\hline 3. & $\begin{array}{c}\text { Post Tes } \\
\text { Siklus II }\end{array}$ & 80,25 & $92,30 \%$ \\
\hline
\end{tabular}


Ini menunjukkan bahwa terjadi peningkatan yang cukup baik. Dapat dikatakan bahwa guru berhasil melakukan perbaikan kegiatan pembelajaran dengan menggunakan metode eksperimen yang terbukti dapat meningkatkan hasil belajar siswa pada pembelajaran SAINS materi sifat-sifat cahaya dan penereapannya di kelas V SD Negeri 101896 Kiri Hulu 1 Tanjung Morawa. Maka dapat dikatakan pula bahwa hipotesis tindakan terbukti dan dapat diterima yaitu "Dengan menerapkan metode eksperimen dapat meningkatkan ketuntasan belajar pada pembelajaran SAINS di kelas V SD Negeri 101896 Kiri Hulu 1 Tahun ajaran $2014 / 2015$.

\section{KESIMPULAN}

Berdasarkan hasil penelitian dapat disimpulkan beberapa hal sebagai berikut:

a. Dengan menerapkan Metode Eksperimen dapat meningkatkan ketuntasan belajar siswa dalam memahami materi pelajaran, lebih berminat, bersemangat, dan termotivasi pada mata pelajaran Sains materi Sifat-sifat Cahaya dan Penerapannya melalui pelaksanaan beberapa rangkaian kegiatan percobaan sederhana membuat alat-alat optik dan berbagai percobaan lainnya di kelas V SD Negeri 101896 Kiri Hulu 1 Tanjung Morawa Tahun Ajaran 2014/2015. Metode Eksperimen dapat memberikan kesempatan pada siswa untuk bekerja sama, saling memberikan saran dan saling membantu untuk memahami materi pelajaran.

b. Ketuntasan belajar merupakan hasil belajar yang dicapai atau diperoleh siswa berkat adanya usaha atau pikiran yang dinyatakan dalam bentuk penguasaan, pengetahuan dan kecakapan dasar yang terdapat dalam berbagai aspek kehidupan sehari-hari . Penerapan metode eksperimen dapat meningkatkan ketuntasan belajar siswa pada pembelajaran Sains materi sifatsifat cahaya dan penerapannya di kelas V SDN 101896 Kiri Hulu 1 Tanjung Morawa. hal ini dapat dilihat dari nilai rata-rata siswa pada saat tes awal (pre test) sebelum diberikan tindakan sebesar 55,51 dengan ketuntasan klasikal 12,8 \% dan dinyatakan belum tuntas. Ketika dilaksanakan post tes siklus I nilai rata-rata meningkat sebesar 69,35 dan ketuntasan klasikal 48,71 \%. Pada tes siklus II nilai rata-rata juga meningkat menjadi 80,25 dengan ketuntasan klasikal menjadi 92,30 $\%$ sehingga sudah mencapai kriteria keberhasilan yang telah ditetapkan.

Berdasarkan hasil pembahasan, maka peneliti memberikan saran-saran yang kiranya berguna dalam proses pembelajaran :

a. Mengingat Metode Eksperimen dapat meningkatkan ketuntasan belajar siswa pada pembelajaran Sains materi Sifat-sifat Cahaya, maka hendaknya guru menerapkan Metode Eksperimen di Kelas V SD sebagai selingan metodemetode pembelajaran yang sudah ada.

b. Kepada para peneliti di dalam pendidikan di sarankan untuk melakukan PTK dengan menggunakan Metode Eksperimen pada materi pembelajaran Sains lainnya, di kelas V SD, untuk mengetahui keberhasilannya.

c. Hendaknya dalam pelaksanaan Metode Eksperimen disaat proses pembelajaran guru memberikan 
bimbingan dan pengawasan secara langsung, mengingat Metode Eksperimen ini menekannkan pada objeknya langsung.

\section{DAFTAR RUJUKAN}

Ardial, Bahdin Nur. 2010. Pedoman Penulisan Karya Ilmiah. Jakarta : Kencana.

Aunurrahman. 2012. Belajar dan Pembelajaran. Bandung:

Alfabeta.

Dewi Rosmala. 2010. Profesionalisasi Guru Melalui Penelitian Tindakan Kelas. Medan : Pasca Sarjana Unimed .

Faturrahman Pupuh. 2007. Strategi Belajar Mengajar. Bandung: Refika Aditama.

Herman dan Yustiana. 2014. Penilaian Belajar Siswa di Sekolah. Yogyakarta: Kansius.

Istarani. 2012. Kumpulan 39 Metode Pembelajaran. Medan: ISCOM MEDAN.

Jalil, Jasman. 2014. Panduan Mudah Penelitian Tindakan Kelas (PTK). Jakarta: Prestasi Pustaka.
Purwanto. 2011. Evaluasi Hasil Belajar. Yogyakarta: Pustaka Belajar.

Panut, dkk. 2007. Dunia IPA di Kelas V $S D$. Bandung : Yudhistira.

Roestiyah N.K. 2001. Strategi Belajar Mengajar. Jakarta: Rineka Cipta.

Sabri Ahmad. 2007. Strategi Belajar Mengajar Micro Teaching. Jakarta : Quantum Teaching. Sagala, Syaiful. 2012. Konsep dan Makna Pembelajaran. Bandung : Alfabeta.

Slameto. 2010. Belajar dan Faktor-fakor yang Mempengaruhi. Jakarta : Rineka Cipta.

Syaiful Bahri Djamarah dan Aswan Zain. 2006. Strategi Belajar Mengajar. Jakarta: Rineka Cipta.

Tantawi, Isma. 2014. Bahasa Indonesia Akademik. Bandung: Ciptapustaka Media.

Tim Kreatif. 2008. Ilmu Pengetahuan Alam SD/MI Kelas V. Jakarta Bumi Aksara.

Trianto. 2010. Model Pembelajaran Terpadu. Jakarta: Bumi Aksara. 